\title{
Gold Extraction to Ferrosilicium, Production of Foam Silicate from Processing Tails of the Olimpiada Mining and Processing Complex Gold Processing Plant (Russia, Krasnoyarsk Territory)
}

\author{
A. Sazonov ${ }^{1(\bowtie)}$, V. Pavlov ${ }^{2}$, S. Silyanov ${ }^{1}$, and E. Zvyagina ${ }^{1}$ \\ ${ }^{1}$ Siberian Federal University, Krasnoyarsk, Russia \\ Sazonov_am@mail.ru \\ 2 Special Design and Technology Bureau "Science", Krasnoyarsk, Russia
}

\begin{abstract}
The paper describes the studies of processing tails of the Olimpiada Mining and Processing Complex with the methods of chemical, mineralogical, electronic microscope, deep reductive melting with division of the melt into a silicate and metal parts. It is demonstrated that $85 \%$ of the processing tails consist of the oxides: $\mathrm{SiO}_{2}, \mathrm{CaO}, \mathrm{Al}_{2} \mathrm{O}_{3}, \mathrm{Fe}_{2} \mathrm{O}_{3}, \mathrm{H}_{2} \mathrm{O}$ and $\mathrm{CO}_{2}$. The distribution of gold and silver is provided by the size classes of the initial blend, after melting of which in reduction conditions re-distribution of gold to the metal phase of the melt occurs. The silicate part of the melt when released into water in the "thermal shock" mode forms a light porous X-ray amorphous material "foam silicate", which also serves as a resource for stable chemical composition for production of a wide range of import substituting ceramic materials.
\end{abstract}

Keywords: Pyrometallurgy $\cdot$ Processing tails $\cdot$ Ferrosilicium $\cdot$ Gold extraction

\section{Introduction}

The development of the methods of flotation, gravity and metallurgic processing of gold bearing ores and man-made products today is aimed at increase of the recovery of the valuable product (Pavlov 2005; Pavlov et al. 2015; Meimanova and Nogayeva 2014; Bogdanovich et al. 2013; Tselyuk and Tselyuk 2013; Algebraistova et al. 2017; Amdur et al. 2015). There are almost no technologies for comprehensive use of processing tails to produce an additional marketable product both for task of comprehensive use of processing tails for production of foamed resources for ceramic items production with associated gold recovery to the ferrosilicium matrix is vital.

\section{Methods}

The paper proposes the pyrometallurgic approach to the solution of the problem of comprehensive wasteless processing of man-made gold-bearing resources with the method of deep reductive melting with division of the melt into the deferrized silicate 
part with its further chilling in the thermal shock mode (Pavlov et al. 2015) and the metal part with associated re-distribution of gold in the ferrosilicium matrix. The specimens of the silicate part of the melt were prepared for study using the powder technology; the metal specimens were covered with epoxy resin with subsequent polishing. The chemical phase composition was studied with the use of an X-ray fluorescent S2 RANGER analyzer and the scanning electronic microscope (SEM) Hitachi S-3400N with EMF Bruker.

\section{Samples}

The input material for pyrometallurgic extraction of gold is represented by the tails of the gold processing plant of the Olimpiada Mining and Processing Complex, which is the leader in Russia in terms of the ore processing volumes and marketable gold production. The gold-antimony and gold-arsenic ores of the Olimpiada deposit have a complex mineral composition and are extremely refractory for gold recovery from them. Most of gold is in the form of thin dissemination in sulfides (Kirik et al. 2017; Novozhilov et al. 2014). No more than $50 \%$ of gold is extracted by direct cyanation. At the gold processing plant the flotation concentrates of the ores are exposed to biooxidation using the BIONORD® technology and subsequent leaching to release gold capsuled in sulfides.

The processing tails have loose consistence, mainly sand-aleuritic-clayey size, with the content of $(-0.071) \mathrm{mm}$ fraction of about $25 \%$. The chemical composition is dominated by $\mathrm{SiO}_{2}, \mathrm{CaO}, \mathrm{Al}_{2} \mathrm{O}_{3}, \mathrm{H}_{2} \mathrm{O}$ and $\mathrm{CO}_{2}$, the share of which is about 90 wt. $\%$. The concentrations of $\mathrm{S}$ are $0.69 \%, \mathrm{C}-2.35 \%, \mathrm{Sb}-0.11 \%, \mathrm{As}-0.19 \%$, and $\mathrm{Ag}$ $-<.1 \%$. The gold grade in individual samples as per the fire assay data varies from 0.2 to $0.97 \mathrm{~g} / \mathrm{t}$, with the average metal grade in the bulk sample received for study of $0.6 \mathrm{~g} / \mathrm{t}$. The main minerals of tails are quartz, calcite and stratified silicates making 98-99\%. Sulfides, oxides, hydroxides and sulfates of iron, arsenic, antimony and tungsten are the impurities. In addition to the native highcarat gold, aurostibite $\left(\mathrm{AuSb}_{2}\right)$ and jonassonite $\left(\mathrm{AuBi}_{5} \mathrm{~S}_{4}\right)$ are present in single grains. Copper, antimony and mercury impurities are noted in some gold particles. Native gold particles are less than $0.045 \mathrm{~mm}$ in size (90\%). Most of gold is noted in the form of micron inclusions in sulfides, quartz, carbonate and micas. Successive chemical leaching in the tail material using the method (Antropova et al. 1980) identified about $20 \%$ of mobile gold forms (water-soluble, sorbed, ferriforms) and sulfide and telluride forms $\sim 15 \%$.

\section{Results}

In the process of the experiment the flotation tails sample with the weight of $400 \mathrm{~g}$ was mixed with lime $\left(\mathrm{Ca}(\mathrm{OH})_{2}\right)$ and brown coal. The blend was exposed to reductive melting at the temperature of $1500-1550{ }^{\circ} \mathrm{C}$, in the process of which melt division into a metal and silicate parts occurred. The silicate part of the melt was poured into water 
with production of foamed amorphous material (foam silicate). The recovery of foam silicate was $150 \mathrm{~g}$. The metal phase recovery was $26 \mathrm{~g}$ (4.4\%). Phase composition of the metal aggregate (wt.\%): ferrosilicum $(\mathrm{FeSi}) 82.8$; xifengite $\left(\mathrm{Fe}_{5} \mathrm{~S}_{3}\right)$ 8.97; wustite $\left(\mathrm{Fe}_{0.974} \mathrm{O}\right)$ 0.79; wollastonite $\left(\mathrm{CaSiO}_{3}\right) 4.24$; calcic clinoferrosilite $\left(\mathrm{Fe}_{1.5} \mathrm{Ca}_{0.5}\left(\mathrm{SiO}_{3}\right)_{2}\right)$ and elemental iron $(\mathrm{Fe})$ 0.49. Chemical composition of the produced foam silicate (wt. \%) - $\mathrm{SiO}_{2}-43.7 ; \mathrm{TiO}_{2}-0.7 ; \mathrm{Al}_{2} \mathrm{O}_{3}-7.79 ; \mathrm{Fe}_{2} \mathrm{O}_{3}-0.19 ; \mathrm{MgO}-2.22 ; \mathrm{CaO}-42.5$; $\mathrm{K}_{2} \mathrm{O}-1.5 ; \mathrm{SO}_{3}-0.77 ; \mathrm{Cl}-0.27$, and metal phases: $\mathrm{Si}-23.5 ; \mathrm{Al}-1.6 ; \mathrm{Fe}-66.2 ; \mathrm{Mn}$ -2.22; $\mathrm{Mg}$ 0.47; $\mathrm{Ca}-1.97 ; \mathrm{S}-0.42 ; \mathrm{As}-0.68 ; \mathrm{Cl}-0.14 ; \mathrm{P}-1.0 ; \mathrm{Co}-0.35 ; \mathrm{V}-$ $0.28 ; \mathrm{Cu}-0.21 ; \mathrm{Au}-0.2$; and $\mathrm{Cr}-0.18$. The optical research of the metal alloy showed non-uniform aggregate composition. Six individualized metal phases of more complex composition have been identified in the iron and silicon alloy matrix. Gold is a part of the alloy consisting of (wt.\%): $\mathrm{Au}-0.25-5.11 ; \mathrm{Sb}-0.4-0.7 ; \mathrm{Sn}-0.57-3.30$; As-up to 9.47; $\mathrm{Cu}-4.51-32.07 ; \mathrm{Fe}-59.8-33.8 ; \mathrm{Mn}-7.2-1.33 ; \mathrm{Ga}-0.24-9.38$; and $\mathrm{Si}-14.53-12.96$.

\section{Conclusions}

Therefore, silicate and metallic semi-finished products have been produced as the result of deep reductive melting of processing tails: (1) ferrosilicium, which is a gold collector; (2) foam silicate material as an additional product of the main production, can be used for production of ceramic materials for different purposes. The use of the method of pyrometallurgic processing of processing tails allows mitigating their adverse effect on the environment.

\section{References}

Algebraistova NK, Makshanin AV, Burdakova EA, Markova AS (2017) Processing of precious metal raw materials in centrifugal devices. Non-ferrous Met 1:18-22

Amdur AM, Vatolin NA, Fyodorov SA, Matushkina AM (2015) Movement of disperse drops of gold in porous bodies and oxide melts during heating. Rep Acad Sci 465(3):307-309

Antropova LV, Shuraleva AZ, Farfel LF, Aizenberg FM, Priyemov GA (1980) Forms of gold occurrence in the rock. Explor Met Eng 136:5-21

Bogdanovich AV, Vasilyev AM, Shneyerson YaM, Pleshkov MA (2013) Gold extraction from stale processing tails of pyritic copper-zinc ores. Ore Process 5:38-44

Kirik SD, Sazonov AM, Silyanov SA, Bayukov OA (2017) Study of disordering in the structure of natural arsenopyrite with the X-ray diffraction analysis of polycrystals and nuclear gamma resonance. J Siberian Federal Univ Eng Technol 10(5):578-592

Meimanova ZhS, Nogayeva KA (2014) Study of flotation processability of stale tails from the Solton-Sary processing plant. Nauka i novye Tekhnologii 2:15-16

Novozhilov YI, Gavrilov AM, Yablokova SV, Arefyeva VI (2014) Unique commercial gold antimony deposit Olimpiada in upper proterozoic terrigenous deposits. Ores Met 3:51-64

Pavlov VF (2005) Physical bases for the technology of production of new materials with set properties on the basis of creation of the system for comprehensive use of man-made and barren resources. Siberian Branch of the Russian Academy of Sciences, Novosibirsk 
Pavlov MV, Pavlov IV, Pavlov VF, Shabanova OV, Shabanov AV (2015) Features of processes of pyrometallurgic processing of polymetallic ores. Chem Benefit Sustain Dev 3:263-266

Tselyuk OI, Tselyuk DI (2013) Prospects of use of gold heap leaching for involvement into commercial development of stale tails of the Eastern Siberia gold processing plants. In: Proceedings of the Siberian Department of the Section of Earth Sciences of the Russian Academy of Natural Sciences, vol 1, no. 42 pp 103-110

Open Access This chapter is licensed under the terms of the Creative Commons Attribution 4.0 International License (http://creativecommons.org/licenses/by/4.0/), which permits use, sharing, adaptation, distribution and reproduction in any medium or format, as long as you give appropriate credit to the original author(s) and the source, provide a link to the Creative Commons license and indicate if changes were made.

The images or other third party material in this chapter are included in the chapter's Creative Commons license, unless indicated otherwise in a credit line to the material. If material is not included in the chapter's Creative Commons license and your intended use is not permitted by statutory regulation or exceeds the permitted use, you will need to obtain permission directly from the copyright holder.

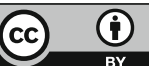

